\title{
Advocates Role in Assistance of the Affected Using Sharp Weapons and Abusing
}

\author{
Agus Ekhsan*) and Umar Ma'ruf*) \\ *) Student of Master of Law, Faculty of Law, Universitas Islam Sultan Agung (UNISSULA) \\ Semarang, E-mail: xsanums@gmail.com \\ ${ }^{* *}$ Faculty of Law, Universitas Islam Sultan Agung (UNISSULA) Semarang
}

\begin{abstract}
Advocate profession is a form of respectable profession (Officium Nobile). The basis for the existence of an Advocate Institute (Legal Advisor) in Indonesia is Act No. 18 of 2003 concerning Advocates. Advocate Assistance is a process of providing ease of solving problems in facing legal processes from clients. The purpose of this research is to know and analyze prosecution procedures, to know and analyze the role of Advocates in the implementation of assistance to the accused and to find out and analyze the factors inhibiting the role of Advocates in the implementation of assistance to the accused of using a sharp weapon and persecution and how to overcome them in the Criminal Case Decision Number: 18/Pid.B/2020/PN Pti. This research uses type research empirical juridical approach, descriptive research specifications. The data used in this study are primary data obtained from field studies which are analyzed qualitatively using law enforcement and justice theories. Then for secondary data obtained from material documents or library materials. Research result conclude that The role of advocates in assisting the accused of using a sharp weapon and maltreatment on behalf of Danang Purwanto bin Parmuji against the verdict of case Number: 18/Pid.B/2020/PN Pti has been maximized with the existence of the right of the defendant's legal counsel to file a defense (Pledoi) of the public prosecutor's criminal charges, presenting a witness who defended the defendant, so that the verdict The Panel of Judges sentenced the defendant to a prison sentence of 4 (four) months and 15 (fifteen) days. It is hoped that in the future there must be moral values and justice for the creation of a common understanding of the law and according to the laws and regulations to achieve a fair legal process in society.

Keywords: Role; Advocates; Weapons; Persecution.
\end{abstract}

\section{Introduction}

The state of Indonesia is a state of law ${ }^{1}$, the affirmation of this constitutional provision means that all aspects of life in society, state and government must always be based on law. The same applies to the legal profession. Whether or not law enforcement works in a society depends on the pros and cons of legal professionals who carry out their profession. Therefore, the increasing human need, the more human need for law. Where the role of advocates is really demanded in carrying out their profession.

Advocate profession is a form of respectable profession (Officium Nobile). The Advocate profession as a law enforcer is based on Act No. 18 of 2003 concerning Advocates and Article 24 Paragraph (1) of the 1945 Constitution. Another characteristic of the Advocate's profession is the giving of trust (usually confidential in nature) from clients (justice seekers) who are expected to carry out

\footnotetext{
${ }^{1}$ Article 1 paragraph (3) of the third amendment of the 1945 Constitution of the Republic of Indonesia.
} 
in a professional manner. ${ }^{2}$ In the rule of law, the State recognizes and protects individual rights. Recognition of individual rights is guaranteed on the basis of equality before the law. For the Indonesian nation human rights, or what are called the rights and obligations of citizens have been stated in the 1945 Constitution which originates from Pancasila. ${ }^{3}$

A person who is a suspect or defendant in a criminal case has the right to get legal assistance from an advocate. According to Vos, a criminal act is a human behavior that is punishable by statutory regulations, so a behavior is generally prohibited with the threat of punishment. ${ }^{4}$ Such as the criminal case that occurred in Pati Regency and was tried at the Pati District Court on behalf of Danang Purwanto Bin Parmuji who had violated Article 2 Paragraph (1) of the Emergency Act No. 12 of 1951 and Article 351 Paragraph (1) of the Criminal Code. The confrontation of the Defendant Danang Purwanto Bin Parmuji before the trial in this case was actually in a very dilemma situation and condition. On the one hand the Defendant with all his might tried to defend himself and for others (his wife), honor, decency or property, because there was an attack or threat of very close attack against the law by 4 (four) people who were in this case was also presented as a witness.

However, in order to find truth and justice, it is proper that there must be a theory of justice and law enforcement which becomes the basis and guideline in such criminal cases. These different arguments are formulated in the form of a decision product that truly reflects a sense of justice for all parties. Presumably, we also agree that law enforcement in criminal cases needs to be prioritized while adhering to the rule of law that a person is found guilty when it is evidently proven legitimate and convincing before the court through a judicial institution's decision. Enforcing criminal law must really be based on the applicable legal rules so that there are no mistakes that violate the constitutional rights of citizens, especially for the Defendant.

\section{Research Methods}

This study uses an empirical juridical approach, the research specification is descriptive. Empirical juridical research includes research on legal identification (unwritten law) and research on legal effectiveness. ${ }^{5}$ The data used in this study are primary data obtained from field studies and conducting interviews which were analyzed qualitatively using law enforcement and justice theories. Then for secondary data obtained from material documents or library materials.In addition, data analysis is presented descriptively, by describing the legality of legal principles and legal aspects related to the role of advocates in assisting defendants using sharp weapons and persecution to achieve a fair legal process.

\footnotetext{
${ }^{2}$ Alkostar, Artidjo. (2010). Peran dan Tantangan Advokat dalam Era Globalisasi. Yogyakarta: Ed. I, FH UII Pres. p.1

${ }^{3}$ Sumarwani, Sri (2012). Pidana dan Hak-Hak Manusia. Semarang: Ed. I, UNDIP Press. p.37

${ }^{4}$ Andrisman, Tri. (2009). Hukum Pidana, Asas-Asas dan Dasar Aturan Umum Hukum Pidana Indonesia. Lampung: University of Lampung. p.70

${ }^{5}$ Susanti, Dyah Ochtorina \& A'an Efendi. (2014). Penelitian Hukum (Legal Research). Jakarta: Sinar Grafika. p.18
} 


\section{Results and Discussion}

\subsection{Prosecution Procedure Against Perpetrators of Criminal Actions Using Sharp Weapons and Persecution In Criminal Case Number 18/Pid.B/2020/PN Pti.}

The Unitary State of the Republic of Indonesia is a country based on democratic laws, based on Pancasila and the 1945 Constitution of the Unitary State of the Republic of Indonesia, not solely based on power. According to Satjipto Rahardjo, progressive law departs from the empirical reality of its role in law in the form of public dissatisfaction and concern for the performance and quality of law enforcement in Indonesia at the end of the 20th century.6 Until now, there are still many Indonesian people who do not understand the procedures in the legal process and the procedures for handling a case at every level of the judiciary, because the socialization and legal education for the community has not fully reached all levels. As for the stages in the prosecution procedure for the perpetrator of a criminal act using a sharp weapon and maltreatment in Criminal Case Number 18/Pid.B/2020/PN Pti in Pati District Court, are:

\subsubsection{Identity of the Perpetrators of the Crime Using Sharp Weapons and Persecution}

Prosecution of the perpetrator of a criminal offense using a sharp weapon and maltreatment at the Pati District Court, namely in cases on behalf of the defendant:

Full name : Danang Purwanto Bin Parmuji

Place of birth : Pati

Age/date of birth : $\quad 26$ Years Old/06-03-1993.

Gender : Male.

Citizenship : Indonesia.

Residence : Krajan Hamlet, Dukuhseti Village Rt. 05/Rw. 01 Dukuhseti District, Pati Regency.

Religion : Islam.

Profession : Entrepreneur.

Education : Junior High School (Graduated). ${ }^{7}$

Whereas the defendant in the Public Prosecutor's Charges was accused of having violated the criminal act of "using a sharp weapon and maltreatment" as regulated and was subject to criminal penalties in Article 2 Paragraph (1) of the Emergency Act No. 12 of 1951 and Article 351 Paragraph (1) of the Criminal Code.

\subsubsection{Position Case}

${ }^{6}$ Ni Made Srinitri, Umar Ma'ruf, Munsharif Abdul Chalim, 2020, Progressivity Of Criminal Handling Fraud And Disease By The Directorate Of The General Criminal Research Of Central Java Regional Police (POLDA), in Jurnal Daulat Hukum Vol 3 (1), Published Master of Law, Faculty of Law UNISSULA. http://dx.doi.org/10.30659/jdh.3.1.\%25p.

7 Prosecution Case File Case Register Number: PDM-05/PATI/Equ. 2/1/2020, March 26, 2020. 
The case for the position of the case is that the defendant Danang Purwanto bin Parmuji on Sunday, 22 December 2019, at around 21.00 WIB located next to a shop owned by Sulas, near the embankment in Krajan Hamlet, Dukuhseti Village, Dukuhseti District, Pati Regency, without the right to control, brought, possessing in his possession, keeping, hiding or using a sharp weapon, stabbing weapon or stabbing weapon in the form of a stainless sword with a length of approximately $66 \mathrm{~cm}$, with an iron handle without being equipped with a valid letter from the authorities

That the defendant Danang Purwanto bin Parmuji on Monday 23 December 2019 at around 02.30 WIB at the defendant's house in Krajan Hamlet, Dukuhseti Village Rt. 05/Rw. 01 Dukuhseti Subdistrict, Pati District, perpetrated the persecution of witnesses Sutrisno als Petel bin Jariyanto (victim) and Ahmad Nur Naim Known as Mating bin Lasno (victim), which was carried out by the defendant.

\subsubsection{Pre-Prosecution Stage}

Pre-prosecution is the authority of the public prosecutor to give instructions to investigators in order to improve the case file, or pre-prosecution is an act of the public prosecutor to provide instructions in the context of improving an investigation by an investigator. In the pre-prosecution, after the Pati Resort police investigator received a copy of the Notification of the Complete Criminal Case Investigation Result (P-21), the investigator then coordinated with the Public Prosecutor at the Pati District Attorney to determine the time to hand over the suspect and case evidence on behalf of Danang Purwanto bin Parmuji.

\subsubsection{Prosecution Stage}

The main task and function of the Prosecutor's Office in the field of criminal law is to prosecute defendants accused of committing a criminal act. The prosecution system in Indonesia is known by 2 (two) principles, namely the legality principle and the opportunity principle. ${ }^{8}$ The activities in the prosecution phase in handling criminal cases using sharp weapons and maltreatment at the Pati District Attorney on behalf of Danang Purwanto bin Parmuji include:

- Acceptance of submission of responsibility for the suspect and evidence from the Police investigator to the Pati District Prosecutor's Office, followed by the Prosecutor to prosecute or hear the case at the Pati District Court (P-16.A);

- The prosecutor then conducts research and re-examination of the suspect and his evidence by interviewing and checking the condition of the evidence (BA-4 and BA-18), then if the suspect is detained, the detention period can be extended by the public prosecutor for 20 days ( $\mathrm{T}-7$ );

- The prosecutor submits the case file and evidence to the Pati District Court for immediate trial (P-33 and P-34);

- The Pati District Court appointed the panel of judges to handle the case, then with an order to determine the day of trial and extend the detention period (BA15), then ordered the prosecutor to confront the defendant, evidence and evidence before the trial according to a predetermined schedule;

${ }^{8}$ AZ, Abidin \& Andi Hamzah. (2010). Pengantar Dalam Hukum Pidana Indonesia. Jakarta: Yarsif Watampone.p.14 
- In a minimum period of 3 days, the prosecutor will immediately notify the defendant (P-37 and P-38 the defendant), then summon witnesses to be presented at trial (P-37 and P-38).

\subsubsection{Execution Stage}

Execution is the final stage of a case settlement process in an integrated criminal justice system adopted in the Criminal Procedure Code. After the public prosecutor carries out the prosecution, delegates the case to the court that has the authority to judge. The District Court has the authority to hear all cases involving criminal acts committed in their jurisdiction. ${ }^{9}$ The activities at the execution stage include: After reading the verdict/verdict of the Pati District Court Judge, the decision letter is immediately given to the Pati District Prosecutor's Prosecutor for immediate execution (if there is no legal remedy by either the prosecutor or the defendant);

JUDGE

- To declare that the aforementioned defendant Danang Purwanto bin Parmuji was legally and convincingly proven guilty of committing a criminal act without the right to use a stabbing weapon or stabbing weapon as in the first indictment and the criminal act of maltreatment as in the second indictment;

- To impose a sentence on the defendant by imprisonment for 4 (four) months and 15 (fifteen) days;

- To determine that the entire period of arrest and detention the defendant has served is deducted from the sentence imposed;

- Determine that the defendant remains detained;

- Determine evidence in the form of: 1 (one) stainless sword blade with a length of approximately $66 \mathrm{~cm}$, with an iron handle wrapped in yellow rope; To be destroyed; 1 (one) black shirt brand hack, on the front that says "HACK" and torn on the back of the lower left;

To be returned to Sutrisno Known as Petel bin Jariyanto;

To charge the defendant a court fee of IDR 2,500.00 (two thousand and five hundred rupiah). ${ }^{10}$ The Prosecutor of the Pati District Prosecutor's Office after receiving the order then executed the defendant by entering a correctional facility or other place designated by the judge or releasing the defendant if the criminal verdict he received was reduced by serving the defendant in prison during the investigation and examination process.

\subsection{The Role of Advocates in Assisting the Defendants Using Sharp Weapons and Persecution In Criminal Case Number 18/Pid.B/2020/PN Pti.}

The role of an advocate or it can be called a legal advisor is a form of respectable role and profession (Officium Nobile). The role of advocates as a free

\footnotetext{
${ }^{9}$ Moch. Isa Nazarudin1 dan Umar Ma'ruf, 2020, Comparison Of The Implementation Of Pre-Court Process Before And After The Constitutional Court Decision Number: 21 / PUU-XII / 2014 In The Batang State Court, in Jurnal Daulat Hukum Vol 3 (1), Published Master of Law, Faculty of Law UNISSULA. http://dx.doi.org/10.30659/jdh.v3i1.8684.

10 Decision Number 18/Pid.B/2020/PN Pti dated April 22, 2020.
} 
and independent law enforcer guaranteed by laws and regulations is very important in the law enforcement process. ${ }^{11}$

In the realm of Indonesian law, the existence and role of an advocate in Indonesia in accompanying a client is very important to be able to defend or fight for the rights of a client. As for the focus of the author in this study is how the role of advocates in assisting the accused of using a sharp weapon and assault on behalf of Danang Purwanto bin Parmuji at the Pati District Court to achieve a fair legal process (due process of law). The defendant gave the power of attorney to Dr. RM. Armaya Mangkunegara, SH, MH, et.all., as an Advocate and/or Legal Consultant at "MANGKUNEGARA Law Firm" having its office address at St. Setia Budi Number 21-H Pati, Phone 082325449195, Postal Code 59115, e-mail: lawfirm@mangkunegara.com

Therefore the Power of Attorney (Legal Counsel) is given the power to:

- Taking legal actions to appear before and/or attend all hearings in order to defend the legal interests of the Authorized Person;

- Take legal actions to attend or accompany the Authorized Person to appear before and/or coordinate with authorized officials in the Police, Attorney General's Office, the RI Prosecutor's Commission, the RI Judicial Commission, the Indonesian Corruption Eradication Commission, and other relevant agencies and ranks;

- Obtaining permission to read, examine and/or request copies of documents relating to the case from the competent authority;

- Making, signing, submitting and/or receiving letters, applications, submitting and/or rejecting evidence, filing objections or defenses as well as making legal remedies for appeal, cassation or review of approval and for the benefit of the Authorized Author;

- In essence, he undertakes all important and useful actions in connection with the handling of the case in the interest of the Authorized Person in accordance with the applicable legal provisions. ${ }^{12}$

Furthermore, based on the provisions of Article 182 paragraph (1) letter b of the Criminal Procedure Code, the defendant and/or his legal adviser are given the right to file a defense of the criminal charges that have been filed by the public prosecutor. Where in this case the role of Advocates in assisting the accused using sharp weapons and maltreatment in Criminal Case Number 18/Pid.B/2020/PN Pti in Pati District Court is an Advocate defending the rights of the defendant in the trial, defending (Pledoi) in writing and read out in court, given the opportunity by the Panel of Judges to present a witness who relieves the defendant in the trial. Thus, based on the theory of justice is to reflect justice to the accused, where the defendant is given his rights at trial through his legal advisor to defend at trial the criminal charges that have been filed by the public prosecutor. So that the theory of

\footnotetext{
11 Tofan Alamsyah, Gunarto, and Umar Ma'ruf, 2020, Legal Form of Relief Is Free Of Charge by the Person or Group of Advocate for the Poor (Study at Jurisdiction in Ex Residency of Cirebon), in Jurnal Daulat Hukum Vol 3(1), Published Master of Law, Faculty of Law UNISSULA. http://dx.doi.org/10.30659/jdh.v3i1.8373.

12 Interview with Dr. Armaya Mangkunegara., SH, MH (Advocate and/or Legal Consultant at Mangkunegara Law Firm) on Sunday, September 20, 2020 at 09.20 WIB.
} 
justice is a theory that studies and analyzes the impartiality, truth, or injustice of institutions or individuals to society or other individuals. ${ }^{13}$ Based on the theory of law enforcement, law enforcement by the Panel of Judges in this trial must really look at the criminal elements that are fulfilled for the acts committed by the defendant against criminal charges to achieve a system and legal process that is fair and acceptable to the community.

\subsection{Factors Inhibiting the Role of Advocates in Assisting the Accused Using Sharp Weapons and Torture and How to Overcome Them.}

It is necessary to understand together that the role of Advocates in the implementation of assistance to defend the defendant does not mean to convey arguments that blame each other among many interests. On the other hand, through assistance and advocacy, it is hoped that an atmosphere of law enforcement is fair and prioritizes objectivity in a space that is guaranteed and protected by the provisions of laws and regulations. In practice, what happened in the field, in the implementation of prosecution against the perpetrator of a criminal offense using a sharp weapon and torture at the Pati District Court, there were still factors that hindered the role of Advocates in the implementation of assistance for the accused of using a sharp weapon and torture at the Pati District Court. and how to overcome it in order to achieve due process of law (fair legal process), including the following:

- The consequences of the defendant exercising his constitutional rights must be reported back;

- That the elements of Article 2 Paragraph (1) of the Emergency Act No. 12 of 1951 and Article 351 Paragraph (1) of the Criminal Code against the accused is linked to the facts revealed at trial;

- Witness testimony that is relevant and related to the indictment submitted by the Public Prosecutor (JPU) as well as documentary evidence at the trial.

Furthermore, the efforts of the Advocate (Legal Advisor) to overcome the factors inhibiting the role of the Advocate in assisting the accused of using sharp weapons and maltreatment as mentioned above, which can be carried out so far are as follows:

- Organizing knowledge sharing between fellow law enforcers and related agencies;

- To disseminate legal education regarding criminal acts using a sharp weapon and persecution;

- Another effort is to improve the performance of Advocates, namely by increasing Human Resources as early as possible.

From the above discussion, based on the theory of justice against factors inhibiting the role of advocates in assisting defendants using sharp weapons and persecution and how to overcome them, that does not reflect justice to the defendant. Where the consequences of the defendant exercising his constitutional rights must be reported back, the defendant should be a victim of beatings and the

\footnotetext{
${ }^{13}$ Salim \& Erlies Septiana Nurbani. (2014). Penerapan Teori Hukum Pada Penelitian Disertasi dan
} Tesis. Jakarta: PT Raja Grafindo Persada. p.26 
right of the defendant as a victim who reports to the police on the incident of beatings experienced by the defendant and his wife. Based on the theory of law enforcement, that based on the provisions of Article 49 of the Criminal Code, the Defendant's action fulfilled the element of forced defense, so that there was no law against the act committed by the Defendant as the Public Prosecutor's Indictment.

\section{Conclusion}

The role of advocates in assisting the accused of using sharp weapons and maltreatment in Criminal Case Number 18/Pid.B/2020/PN Pti in Pati District Court is the presence of Advocates to defend and represent the rights of the defendants in court, Advocates carry out the defense (Pledoi) of the demands made by the public prosecutors and advocates is given the opportunity for the panel of judges to be able to present witnesses to relieve the defendant, so that a fair legal process can be created in the decision of the panel of judges against the accused.

\section{References}

Journal:

[1] Moch. Isa Nazarudin1 dan Umar Ma'ruf, 2020, Comparison Of The Implementation Of Pre-Court Process Before And After The Constitutional Court Decision Number: 21 / PUU-XII / 2014 In The Batang State Court, in Jurnal Daulat Hukum Vol 3 (1), Published Master of Law, Faculty of Law UNISSULA. http://dx.doi.org/10.30659/jdh.v3i1.8684.

[2] Ni Made Srinitri, Umar Ma'ruf, Munsharif Abdul Chalim, 2020, Progressivity Of Criminal Handling Fraud And Disease By The Directorate Of The General Criminal Research Of Central Java Regional Police (POLDA), in Jurnal Daulat Hukum Vol 3 (1), Published Master of Law, Faculty of Law UNISSULA. http://dx.doi.org/10.30659/jdh.3.1.\%25p.

[3] Tofan Alamsyah, Gunarto, and Umar Ma'ruf, 2020, Legal Form of Relief Is Free Of Charge by the Person or Group of Advocate for the Poor (Study at Jurisdiction in Ex Residency of Cirebon), in Jurnal Daulat Hukum Vol 3(1), Published Master of Law, Faculty of Law UNISSULA. http://dx.doi.org/10.30659/jdh.v3i1.8373.

Books:

[1] Alkostar, Artidjo. (2010). Peran dan Tantangan Advokat dalam Era Globalisasi. Yogyakarta: Ed. I, FH UII Pres

[2] Andrisman, Tri. (2009). Hukum Pidana, Asas-Asas dan Dasar Aturan Umum Hukum Pidana Indonesia. Lampung: University of Lampung

[3] AZ, Abidin \& Andi Hamzah. (2010). Pengantar Dalam Hukum Pidana Indonesia. Jakarta: Yarsif Watampone

[4] Salim \& Erlies Septiana Nurbani. (2014). Penerapan Teori Hukum Pada Penelitian Disertasi dan Tesis. Jakarta: PT Raja Grafindo Persada

[5] Sumarwani, Sri (2012). Pidana dan Hak-Hak Manusia. Semarang: Ed. I, UNDIP Press

[6] Susanti, Dyah Ochtorina \& A'an Efendi. (2014). Penelitian Hukum (Legal Research). Jakarta: Sinar Grafika 


\section{Regulations:}

[1] The Constitution of the Republic of Indonesia 1945

[2] Book of Civil Code

\section{Others Documents:}

[1] Case Decision File Number 18/Pid.B/2020/PN Pti dated April 22, 2020.

[2] Prosecution Case File Case Register Number: PDM-05/PATI/Equ. 2/1/2020, March 26, 2020.

Interview:

Interview with Dr. Armaya Mangkunegara., SH, MH (Advocate and/or Legal Consultant at Mangkunegara Law Firm) on Sunday, September 20, 2020 at 09.20 WIB. 